\title{
IMMANUEL MAURICE WALLERSTEIN
}

(1930-2019)

\section{Christopher Chase-Dunn}

Institute for Research on World-Systems, University of California-Riverside

\section{Hiroko Inoue}

Institute for Research on World-Systems, University of California-Riverside

\section{Thomas D. Hall}

DePauw University

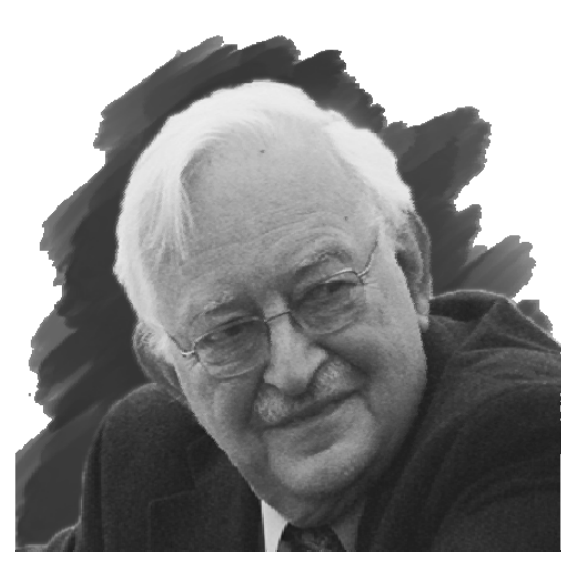

Immanuel Wallerstein was one of most influential social theorists of recent decades. His approach to world history, which he called the 'world-system perspective,' had a wide and deep impact throughout the social sciences and humanities. Wallerstein was born in New York City on September 28, 1930. He earned his B.A. (1951), M.A. (1954), and Ph.D. (1959) at Columbia University, where he taught until 1971. Columbia housed outstanding intellectuals such as Karl Polanyi, Lionel Trilling, Richard Hofstadter and C. Wright Mills. Wallerstein's intellectual development reached from New York City to Paris, Ghana, and the Ivory Coast. While in Paris he became familiar with the work of the Annales School, a legacy of Fernand Braudel. He also worked with Georges Balandier, sociologist, anthropologist and ethnologist who focused on African colonialism.

As an undergraduate at Columbia Wallerstein took classes from C. Wright Mills during the period in which he (Mills) was writing The Power Elite. Mills was disaffected with the predominant theoretical and methodological approaches in sociology (abstracted empiricism and grand theory). Wallerstein, like Mills, helped to create a new way of looking at societies that was intended to renew the possibility of achieving human freedom.

For his dissertation, later published as The Road to Independence: Ghana and the Ivory Coast (1964) Wallerstein conducted research on the voluntary associations that led

Journal of Globalization Studies, Vol. 10 No. 2, November 2019 138-141 
the West African independence movements. Wallerstein conducted interviews and surveys in the Gold Coast (later Ghana) and the Ivory Coast. His studies of the rise and demise of colonial regimes in Africa led him to conclude that comprehension of African history and social change required attention to the historical and contemporary interactions among Africa, Europe and the Americas.

Wallerstein was on the faculty at Columbia during the 1960s, an era of international student revolt including the Civil Rights movement in the United States, the anti-war movement stimulated by the war in Vietnam, and a counter-cultural rebellion that made alliances with students and radical workers in France and Italy. Later he called this 'the world revolution of 1968.' In 1971 he moved to McGill University for five years, then on to Binghamton University. There, along with Terence Hopkins, he founded the Fernand Braudel Center for the Study of Economies, Historical Systems and Civilizations. In the early 1990s Wallerstein chaired the international Gulbenkian Commission on the Restructuring of the Social Sciences. In 2000 he became a senior research scholar at Yale. He was a past president of the International Sociological Association, and he published more than 30 books and over 200 articles and book chapters (see http://iwallerstein.com/wp-content/uploads/docs/iwallerstein-cv-eng-09.pdf).

At Columbia Wallerstein came to see intellectual and political projects as two sides of the same coin. He became interested in Dependency Theory, the idea that there is an international hierarchy that underdevelops the Global South. Dependency theory had emerged primarily among Latin American scholars such as Raul Prebisch, Teotonio Dos Santos, Anibal Quijano and Fernando Henrique Cardozo. It was popularized in the Global North by Andre Gunder Frank. Over the ensuing years Wallerstein, along with Giovanni Arrighi and Samir Amin, used the concept of an evolving hierarchical global division of labor to analyze world history. Fruitful collaboration and debate among Frank, Amin, Arrighi, and Wallerstein continued throughout their lives.

The rise of the World-System Perspective. Wallerstein and the dependency theorists argued that core-periphery relations went far beyond formal colonialism. Wallerstein noticed that similar colonial-like relations had existed between Poland and Western Europe during sixteenth century. He discussed this in detail in the first volume of The Modern World-System published in 1974. The world-system perspective explains institutional changes by focusing on whole interpolity systems and transnational relations in contrast to the usual social science focus on single national societies (methodological nationalism). Wallerstein argued that societies have always existed within larger interaction networks that shaped their histories. Long before globalization became a catch word, the world-system perspective examined the nature of a world economy that linked a system of interacting polities. Wallerstein defined three kinds of systems: minisystems based on reciprocity, world-empires based on redistribution, and world-economies in which multiple states ally and compete with one another. World-system hierarchies are composed of three components: 1) the core, which contains the most developed societies; 2) the periphery, which is composed of the least developed societies; and 3) the semiperiphery, which is composed of societies intermediate between core and peripheral societies. The word 'world' means a largely self-contained system, so there were several world-systems on Earth before the Europe- 
centered system incorporated the others into the modern global system. The semiperiphery helps to stabilize the overall system. While the core-peripherysemiperiphery structure relatively constant, the positions of individual firms and states can shift over time. There is some upward and downward mobility, but not much.

Wallerstein saw the normal condition of world-economies to be multicentric in the sense that the core contains several power polities that are allying and competing with one another. This condition was thought to contrast with earlier world empires in which a single state had conquered the other core states. Wallerstein also focused on the rise and fall of hegemonic core states in the modern system. He saw a seventeenth-century Dutch hegemony that was followed in the nineteenth century by the British hegemony and in the twentieth century by the U.S. hegemony.

Wallerstein argued that the modern world-system emerged in the long sixteenth century (1560-1640) when Europeans first circumnavigated the globe and began colonizing and exploiting other continents. He contends that the Dutch hegemony peaked during the economic and demographic crisis of the seventeenth century. Then Great Britain and France contended for hegemony in the eighteenth century. Britain eventually came to dominate the system in the nineteenth century. The United States rose to hegemony in the twentieth century and is now in a phase of hegemonic decline.

So, for Wallerstein capitalism became the predominant logic of accumulation in the regional (European) world-system in the sixteenth century. This system then grew larger in a series of cycles and upward trends and is now approaching upper limits (asymptotes): 1. the long-term rise of real wages; 2 . the long-term costs of material inputs; and 3. taxes. These long-term (meaning centuries) trends lead to a fall in the average rate of profits. Strategies combating these trends - automation, capital flight, acceptance of reduced wages in order to remain employed, attacks on the welfare state, and on unions slow down, but do not eliminate, the contradictions of capitalism. This has led to an irreconcilable structural crisis and period of chaos that will continue for the next 50 years, an 'Age of Transition.' The results of this transition are far from clear or fixed. Possibilities range from a global fascist state to some form of collectively rational egalitarian and democratic global governance.

Wallerstein was intentionally vague about what might replace capitalism. He argued that the declining hegemony of the United States and the crisis of neoliberal global capitalism are signs that capitalism can no longer adjust to its own contradictions. Thus, the world is in a period of chaotic and unpredictable historical transformation. The new system that eventually emerges might be an authoritarian global state that preserves the privileges of the global elite or an egalitarian system in which non-profit institutions serve communities. Wallerstein agreed with those who have argued that taking state power, as happened in the Russian Revolution in 1917 and the decolonization movements, is more likely to reproduce capitalism than to replace it with a more egalitarian system. He was a leader of the global justice 'movement of movements' that emerged in the context of the World Social Forum process. Immanuel died on August 31, 2019 at his home in New Haven, Connecticut.

Though there have been many other contributors, Immanuel Wallerstein was the major founder of the world-system perspective. His outstanding work as a historical 
sociologist and a public intellectual demonstrate that social theory is not only for academics. His work is being carried on in several institutional contexts by younger generations of world-system scholars and global justice activists. The struggle continues.

\section{FURTHER READINGS}

Arrighi, G., and Goldfrank W. L. (eds.) 2000. Festschrift for Immanuel Wallerstein. Journal of WorldSystems Research VI: 150-945.

Babones, S., and Chase-Dunn, C. (eds.) 2012. Routledge Handbook of World-Systems Analysis. London: Routledge.

Wallerstein, I. (ed.) 2000. The Essential Wallerstein. New York: New Press.

Wallerstein, I. 2004. World-Systems Analysis: An Introduction. Durham, NC: Duke University Press.

Wallerstein, I. 2011. The Modern World-System I: Capitalist Agriculture and the Origins of the European World-Economy in the Sixteenth Century, with a new Prologue. Berkeley: University of California Press (reprint of 1974 original).

Wallerstein, I. 2011. The Modern World-System II: Mercantilism and the Consolidation of the European World-Economy, 1600-1750, with a new Prologue. Berkeley: University of California Press (reprint of 1980 original).

Wallerstein, I. 2011. The Modern World-System III: The Second Era of Great Expansion of the Capitalist World-Economy, 1730-1840s, with a new Prologue. Berkeley: University of California Press (reprint of 1989 original).

Wallerstein, I. 2011. The Modern World-System IV: Centrist Liberalism Triumphant, 1789-1914. Berkeley: University of California Press. 